
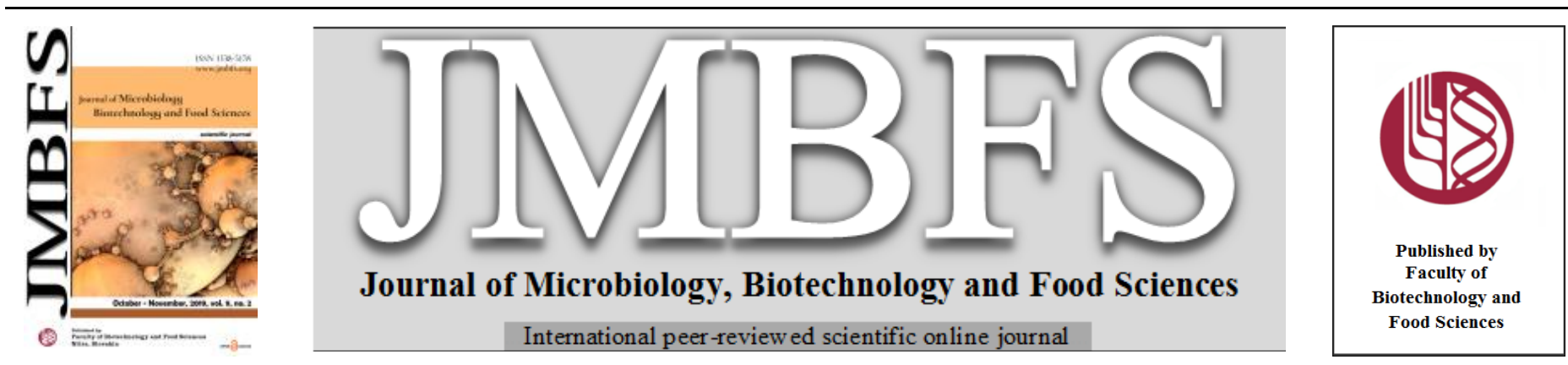

\title{
MORPHOLOGICAL AND MOLECULAR CHARACTERISATION OF EGUSI MELON (CITRULLUS LANATUS (THUMB) MATSUM AND NAKAI) FOUND IN DIFFERENT ECOLOGICAL ZONES IN NIGERIA
}

\author{
Norbert Awiligwe ${ }^{* 1}$, Nkechi Egbe ${ }^{2}$ and Benjamin C. Onusiriuka ${ }^{3}$ \\ Address(es): Department of Biological Sciences, Nigerian Defence Academy, PMB 2109, Kaduna, Nigeria
}

*Corresponding author: awiligwe21@gmail.com

doi: 10.15414/jmbfs.2019.9.2.222-227

\section{ARTICLE INFO}

Received 30. 10. 2018

Revised 1. 4. 2019

Accepted 4. 4. 2019

Published 1. 10. 2019

Regular article

OPEN $\partial_{\text {ACCESS }}$

\begin{abstract}
Ten accessions of egusi melon were investigated using seed morphology, percentage protein and fat content as well as their molecular characters. The morphological features of the seeds revealed, they range in size from medium to large brown or golden yellow with thin or thick edge. The results obtained for percentage seed fat content showed SMATK-KD (43.90) and MAD- NG (43.69) had the highest mean values while the least mean value for percentage seed fat content was obtained from KTGO-GMB (20.07). Results obtained for percentage seed protein content revealed that the accessions KTGO-GMB (23.50) and OKIJA-AN (17.59) had highest mean values for protein content while GUS-ZAM (13.96) and AGU-ENU (14.35) produced the least mean values. The results obtained for seed weight revealed that AGU-ENU (12.90) and KTGO-GMB (12.45) had the highest mean weight obtained for 100 seeds while OKIJA-AN (10.8) and MAS-NAS (10.90) had the least mean weight values. Total genomic DNA was extracted using Cetyl Trimethyl Ammonium Bromide (CTAB) protocol. Genetic relatedness and variation was determined by Random Amplified Polymorphic DNA (RAPD) PCR analysis. Three primers were used, OPA 13, OPA 16 and OPA 18. The results of dendrogram obtained from the pooled data revealed high level of dissimilarity or diversity of $67.5 \%$ among the accessions of the melon. RAPD markers are suitable in assessing genetic diversity and can aid in the identification of desirable qualities for the introduction of new genes into breeding materials.
\end{abstract}

Keywords: Egusi melon, RAPD PCR, Morphological

\section{INTRODUCTION}

Egusi-melon (Citrullus lanatus (Thumb.) Matsum \& Nakai) is a member of the Cucurbitaceae family (Schippers, 2000). It is a variety of melon seed which is popularly called 'Egusi' in West Africa (Akpambang et al., 2008). Other common names include, 'Ibara', wild watermelon (Abrefa, 2003) and egusimelon (Ayodele and Salami, 2006; Idehen et al., 2008; Ojieh et al., 2008). The crop is widely cultivated in Nigeria (Ezeike and Offen, 1989; Jolaoso et al., 1996; Anuebunwa, 2000) and other African countries for its seeds (Ogbonna and Obi, 2007). The seeds provide a well relished condiment for soup. It is rich in vegetable protein, fat and vitamins (Rehn and Espig, 1991; Fayemi, 1999, Adewusi et al., 2000). The seeds contain up to $50 \%$ oil (Olaefa et al., 1994; Fakou et al., 2004; Achu et al., 2005) and 35\% protein (Fakou et al., 2004).

In spite of the nutritional value of egusi - melon, its benefit to farmers and the land this nutritional age - old resource is languishing (DSC, 2006). It is one of the most neglected vegetable crops in tropical agricultural research (William and Isaq, 2002; Makinde et al., 2014). Idehen et al., (2007) noted that the only breeding work that has been done on egusi-melon that is directed towards producing a high yielding variety has been limited to selection based on the examination of varietal differences. If given attention, the plant is likely not only to improve nutrition but also farmer's income (DSC, 2006)

Characterization of closely related plant species is nowadays greatly supported via examination of various decisive genetic criteria such as random amplified polymorphic DNA (RAPD) (Adeyemo and Ojo, 1991). It is reported as a promising tool for the authentication of medicinal plant species and especially useful in species or varieties that are morphologically and/or phytochemically indistinguishable (Adeyemo and Ojo, 1991). Molecular marker technologies offer alternatives for the identification of accessions and genetic diversity.

Idahosa et al., (2010) noted that the magnitude of genetic variability present in the base population of any crop species is important in crop improvement and as such must be exploited by plant breeders for yield improvement. Other factor important to the plant breeder includes the morphological as well the physico chemical parameters in terms of percentage fat and protein content (Ndukauba $\boldsymbol{e t}$ $\boldsymbol{a l}$, 2015). RAPD has been used to resolve taxonomic relationships providing a quantitative measure of genetic diversity between species and genres (Silberstein et al., 1999). The variability among European melon breeds using RAPD molecular marker was relatively low compared to lentils Garco-Rodrigez et al., 1996).

Furthermore, Mliki et al., (2001) studied genetic differences among African melon landraces using molecular markers. Their results revealed variation among landraces. Erdine et al., (2015) also studied the genetic diversity of Turkish landraces of melon by RAPD and ISSR primers, their result also showed variation between accessions. RAPD and ISSR markers selected to characterize the traditional landraces of curcumins melon groups in Palestine, because it is informative, easy to use, cheap, and quick and no sequence information required, (Zhang et al., 2012). The aim of this study is to do a morphological and molecular characterisation of Egusi-melon (Citrullus Lanatus (Thumb) Matsum and Nakai) found in different ecological zones in Nigeria.

\section{MATERIALS AND METHODS}

\section{Evaluation of ten egusi-melon accessions}

Ten egusi-melon accessions collected from five ecological zones of Nigeria were used for the experiment. Each accession was given a code name for easy identification. Two (2) of the accessions each were obtained from the Derived savannah ecological zone, Forest ecological zone, Northern Guinea Savanna, Southern Guinea Savanna and Sudan Savannah respectively

\section{Extraction}

Dried and de-hulled Egusi Seed samples per accession were ground by using mortar and pestle to fine powder and genomic DNA was extracted by using the Cetyl Trimethyl Ammonium Bromide (CTAB) method (Doyle and Doyle, 1987).

\section{Random Amplified Polymorphic DNA (RAPD) assay}

Three RAPD primers were used, RAPD-PCRs were performed using random decamer sets according to Williams et al., (1993).The reactions were performed twice for each primer by thermo cycler in $25 \mu 1$ reaction volumes containing the following: $30 \mathrm{ng}$ genomic DNA, $0.2 \mathrm{mmol} / \mathrm{l}$ primer, 0.5 unit taq DNA polymerase, $0.1 \mathrm{mmol} / 1$ of each $\mathrm{dNTP}, 1.5 \mathrm{mmo} 1 / 1 \mathrm{MgCl}_{2}$, and reaction buffer 
$\left(1.5 \mathrm{mmo1} / \mathrm{l} \mathrm{MgCl}_{2}, 10 \mathrm{mmo1} / \mathrm{l}\right.$ Tris-HC1 $(\mathrm{pH}=9), 50 \mathrm{mmol} / \mathrm{l} \mathrm{KC1}, 0.1 \%$ volume fraction of Triton X-100, and $0.2 \mathrm{mg} / \mathrm{ml}$ bovine serum albumin (BSA)) Amplification included 40 cycles of $1 \mathrm{~min}$ at $94^{\circ} \mathrm{C}, 90 \mathrm{~s}$ at $36^{\circ} \mathrm{C}, 2 \mathrm{~min}$ at $72^{\circ} \mathrm{C}$, with $2 \mathrm{~min}$ initial denaturation, and $5 \mathrm{~min}$ final extension.

RAPD-PCR products was separated by gel electrophoresis (1.5\% agarose, $1 \mathrm{X}$ Tris Acetate EDTA (TAE) buffer, and $0.5 \mu \mathrm{g} / \mathrm{ml}$ ethidium bromide). PCR products were loaded in the gel as follows: $8 \mu 1$ of PCR product and $3 \mu 1$ of $6 \mathrm{X}$ sample loading buffer. Gel was run at voltage $120 \mathrm{~V}$ for 1 hour in $1 \mathrm{X}$ TAE buffer, bands were visualized under a UV trans illuminator and photographed.

Table 1 Sequences of the random primers for RAPD-PCR Analysis

\begin{tabular}{lc}
\hline Primer & Primer Sequence $\left(3^{\prime}-5^{\prime}\right)$ \\
OPA 13 & CAGCACCCAC \\
OPA16 & AGCCAGCGAA \\
OPA 18 & AGGTGACCGT \\
\hline
\end{tabular}

\section{Protein and fat content analysis}

The nitrogen content was determined by Kjeldahl method described by Pearson (1976) and nitrogen content was converted to protein by multiplying by a factor of 6.25. Crude fat content of samples was done by Heating the sample with concentrated $\mathrm{HCl}$.This dissolves the fat and other materials. The fat is then extracted with suitable solvents (diethyl ether).

\section{Data Scoring and Analysis}

Amplified DNA fragments that were reproducible were translated into binary character matrices ( 1 for presence, 0 for absence) (Podani, 2016). The commercial software package SPSS (version 16) was used to develop similarity matrices based on Jaccard coefficient and the data used to construct dendrogram for cluster analysis based on the Jaccard coefficient (Podani, 2016)

Table 2 Code name, ecological zone, description and source of seeds of ten egusi-melon accessions

\begin{tabular}{|c|c|c|c|}
\hline Code name of accessions & $\begin{array}{l}\text { Ecological zone } \\
\text { of accessions }\end{array}$ & Description of seed of accessions & $\begin{array}{l}\text { Source of } \\
\text { accessions }\end{array}$ \\
\hline & Forest regrowth zone & & \\
\hline $\mathrm{OKIJ}-\mathrm{AN}$ & $\begin{array}{l}\text { Okija in Anambra State in the forest regrowth } \\
\text { zone in Nigeria }\end{array}$ & Large, brown seed with thin edge & Farmer \\
\hline $\mathrm{AMZI}-\mathrm{AB}$ & Amizi in Abia State in forest regrowth zone & $\begin{array}{l}\text { Large, brown seed with thin edge } \\
\text { Derived savanna zone }\end{array}$ & Farmer \\
\hline OFATK-KW & $\begin{array}{l}\text { Offa in Kwara State in the derived } \\
\text { savanna zone }\end{array}$ & $\begin{array}{l}\text { Medium, brown seed with thin } \\
\text { edge }\end{array}$ & Farmer \\
\hline AGWU-EN & $\begin{array}{l}\text { Agwu in Enugu State in the derived savanna } \\
\text { zone } \\
\text { Northern guinea savanna }\end{array}$ & Medium, brown seed with thin edge & Farmer \\
\hline SMATK -KD & $\begin{array}{l}\text { Samaru, Zaria in the Northern guinea savanna } \\
\text { zone }\end{array}$ & Large, brown seed with thin edge & Farmer \\
\hline $\mathrm{MAD}-\mathrm{NG}$ & $\begin{array}{l}\text { Madala in Niger State in the northern guinea } \\
\text { savanna zone } \\
\text { Southern guinea savanna }\end{array}$ & Large, brown seed with thick edge & Farmer \\
\hline SULTK - NG & $\begin{array}{l}\text { Suleija, Niger State in the southern guinea } \\
\text { savanna zone }\end{array}$ & $\begin{array}{l}\text { Medium, brown seed with thick } \\
\text { edge }\end{array}$ & Farmer \\
\hline MAS-NAS & $\begin{array}{l}\text { Massaka, Nassarawa State in the southern guinea } \\
\text { savanna zone }\end{array}$ & Large, brown seed with thick edge & Farmer \\
\hline & Sudan savanna & & \\
\hline KTGO - G MB & $\begin{array}{l}\text { Kaltungo in Gombe State in the sudan savanna } \\
\text { zone }\end{array}$ & $\begin{array}{l}\text { Large, golden-yellow seed with thin } \\
\text { edge }\end{array}$ & Farmer \\
\hline GUS-ZAM & $\begin{array}{l}\text { Gusua in Zamfara State in the sudan savanna } \\
\text { zone }\end{array}$ & Large, brown seed with thick edge & Farmer \\
\hline
\end{tabular}

\section{RESULTS AND DISCUSSION}

\section{Results}

\section{Morphology of Egusi Melon Seed Accessions:}

Morphological features of the ten egusi melon seeds revealed that they range in size from medium to large brown or golden yellow seeds with thin or thick edge as shown figure 1

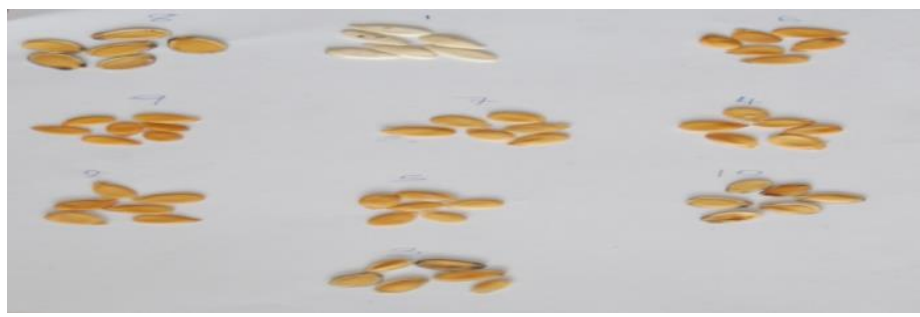

Figure 1 Morphology of egusi-melon seeds accessions , 1 = KTGO-GMB, 2 = SMATK-KD， 3= GUS-ZAM，4 = AMIZI-AB， 5 = OFATK-KW，6= SULTKNG, $7=$ OKIJ-AN, 8= MAD-NG, $9=$ AGWU-EN, and $10=$ MAS-NAS

Variations in the mean seed weight is revealed in figure 3. AGU-ENU (12.90) and KTGO-GMB (12.45) has the highest mean weight obtained for 100 seeds with a range of 12.40-13.40 and 12.10-12.8 respectively.
Other results obtained for seed weight revealed that OKIJA-AN (10.8) MASNAS(10.90) has the least mean weight obtained for 100 seeds with a range of $10.2-11.40$ and $10.10-11.70$ respectively .

SMATK-KD (43.90) and MAD- NG (43.69) obtained the highest mean value for fat content with range values of 43.84-43.95 and 43.66-43.72 respectively as shown in figure 2. On the other hand, the least mean value for percentage seed fat content was obtained from KTGO-GMB (20.07) with a range of 20.05-20.09.

Variations in mean seed protein content is revealed in figure 4. KTGO- GMB (23.50) and OKIJA-AN (17.59) has highest mean values for protein content. On the other hand, GUS-ZAM (13.96) and AGU-ENU (14.35) produced the least mean values for protein content and were associated with a range of 13.91-14.00 and 14.26-14.44 respectively.

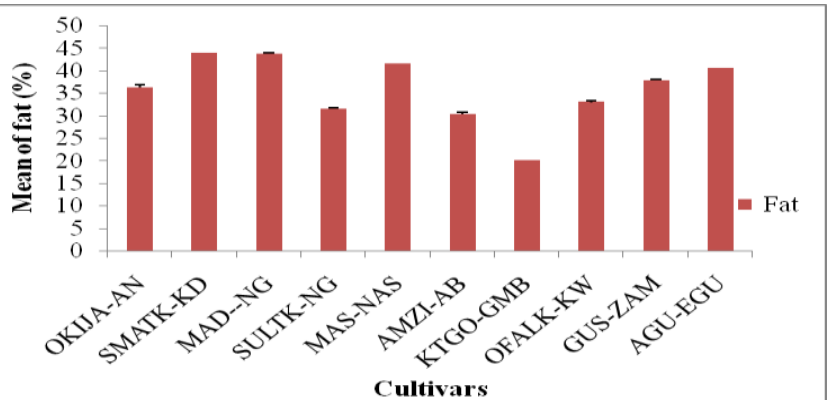

Figure 2 Variations in mean seed percentage fat content of Egusi Melon seed accessions collected from different ecological zones in Nigeria 


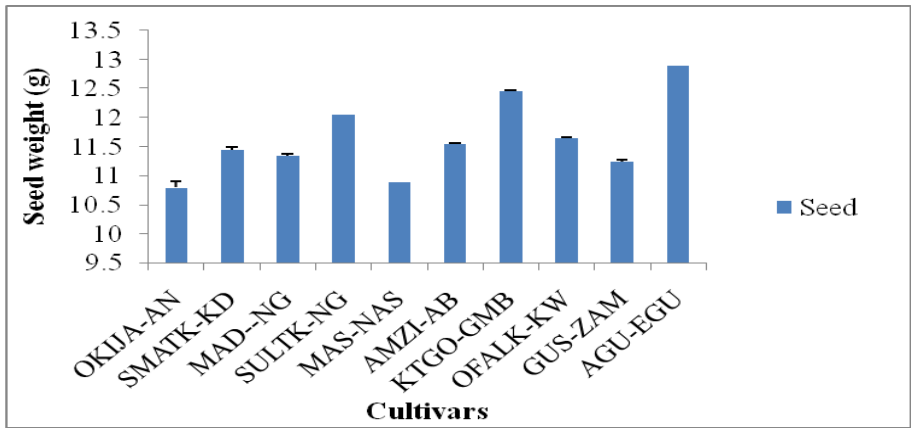

Figure 3. Variations in mean seed weight of Egusi Melon seed accessions collected from different ecological zones in Nigeria

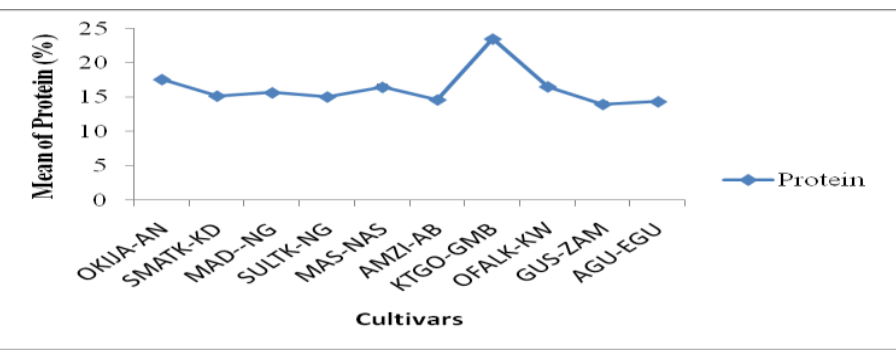

Figure 4 Variations in mean seed percentage protein content of Egusi Melon accessions collected from different ecological zones in Nigeria.

Variations in the mean seed weight, percentage fat and protein content using the Duncan multiple test is as presented in table 3 Means with the same letter and within the same column are not significantly different $(\mathrm{P}>0.05)$ using the Duncan's Multiple Test

Table 3 Variations in the mean seed weight, \% fat and protein using the Duncan multiple test

\begin{tabular}{llll}
\hline accessions & Seed wt $\mathbf{( g )}$ & $\begin{array}{l}\text { Mean Fat } \\
(\boldsymbol{\%})\end{array}$ & $\begin{array}{l}\text { Mean Protein } \\
\mathbf{\%}\end{array}$ \\
\hline OKIJA-AN & $10.8^{\mathrm{a}}$ & $36.28^{\mathrm{f}}$ & $17.59^{\mathrm{b}}$ \\
SMATK-KD & $11.45^{\mathrm{f}}$ & $43.9^{\mathrm{a}}$ & $15.18^{\mathrm{cd}}$ \\
MAD-NG & $11.35^{\mathrm{g}}$ & $43.69^{\mathrm{b}}$ & $15.66 \mathrm{de}$ \\
SULTK-NG & $12.05^{\mathrm{c}}$ & $31.49^{\mathrm{h}}$ & $15.05^{\mathrm{f}}$ \\
MAS-NAS & 10.9 & $41.54^{\mathrm{c}}$ & $16.46^{\mathrm{c}}$ \\
AMZI-AB & $11.55^{\mathrm{e}}$ & 30.39 & $14.62^{\mathrm{fg}}$ \\
KTGO-GMB & $12.45^{\mathrm{b}}$ & 20.07 & $23.5^{\mathrm{a}}$ \\
OFALK-KW & $11.65^{\mathrm{d}}$ & $32.99^{\mathrm{g}}$ & $16.53^{\mathrm{c}}$ \\
GUS-ZAM & $11.25^{\mathrm{h}}$ & $37.77^{\mathrm{e}}$ & 13.96 \\
AGU-EGU & $12.9^{\mathrm{a}}$ & $40.57^{\mathrm{d}}$ & $14.35 \mathrm{fg}$ \\
\hline
\end{tabular}

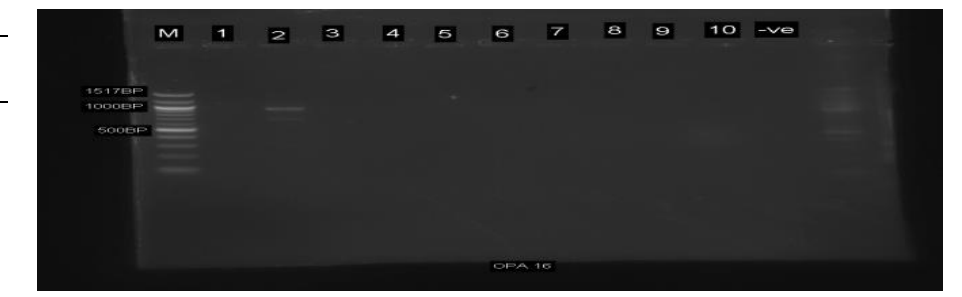

Figure 7 RAPD profiles for ten Egusi melon seed accessions amplified with primer OPA 16. Lane $1=$ KTGO - GMB, lane $2=$ SMATK-KD, lane $3=$ GUS ZAM, lane $4=$ AMIZI-AB, lane $5=$ OFATK-KW, lane 6 SULTK-NG, lane $7=$ OKIJ-AN, lane $8=$ MAD-NG, lanes $9=$ AGWU-EN, and lane $10=$ MAS-NAS,

The Primer Specific Scoring of bands in ten (10) accessions of Egusi Melon Seed obtained from five ecological zones in Nigeria is shown in table 4 .

The number of fragments, polymorphic fragments and percentage polymorphism revealed by RAPD primers is shown in table 5 . While Scorable bands used for the construction of Dendrogram is shown in table 6

Table 4 Primer Specific Scoring of bands in ten (10) accessions of egusi Melon Seed

\begin{tabular}{cccccccccccccl}
\hline \multirow{2}{*}{ Primers } & $\begin{array}{l}\text { Base } \\
\text { Pair }\end{array}$ & 1 & 2 & 3 & 4 & 5 & 6 & 7 & 8 & 9 & 10 & $\begin{array}{l}\text { Band } \\
\text { Pattern }\end{array}$ \\
\hline & 1000 & 0 & 1 & 0 & 0 & 0 & 0 & 0 & 0 & 0 & 0 & Unique \\
& 900 & 0 & 1 & 0 & 0 & 0 & 0 & 0 & 0 & 1 & 0 & Polymorphism \\
& 800 & 0 & 1 & 0 & 0 & 0 & 0 & 0 & 0 & 0 & 0 & unique \\
& 700 & 1 & 1 & 0 & 0 & 0 & 0 & 0 & 0 & 0 & 0 & Polymorphism \\
& 600 & 0 & 1 & 0 & 0 & 0 & 0 & 0 & 0 & 0 & 0 & Unique \\
& 500 & 0 & 1 & 0 & 0 & 0 & 0 & 0 & 0 & 0 & 0 & Unique \\
& 400 & 1 & 1 & 1 & 0 & 0 & 0 & 0 & 0 & 1 & 1 & Polymorphism \\
& 300 & 1 & 0 & 0 & 0 & 0 & 0 & 0 & 0 & 0 & 0 & Unique \\
& 200 & 1 & 0 & 0 & 0 & 0 & 0 & 0 & 0 & 0 & 0 & Unique \\
& 1000 & 0 & 1 & 0 & 0 & 0 & 0 & 0 & 0 & 0 & 0 & Unique
\end{tabular}


OPA 18

\begin{tabular}{|c|c|c|c|c|c|c|c|c|c|c|c|}
\hline 1000 & 0 & 0 & 1 & 0 & 0 & 1 & 0 & 0 & 0 & 0 & Polymorphism \\
\hline 900 & 0 & 1 & 0 & 0 & 0 & 0 & 0 & 0 & 0 & 0 & Unique \\
\hline 800 & 1 & 1 & 0 & 0 & 0 & 0 & 0 & 0 & 0 & 0 & Polymorphism \\
\hline 700 & 1 & 0 & 0 & 0 & 0 & 1 & 0 & 0 & 0 & 0 & Polymorphism \\
\hline 500 & 1 & 0 & 0 & 0 & 0 & 1 & 0 & 1 & 0 & 1 & Polymorphism \\
\hline 400 & 0 & 1 & 0 & 0 & 0 & 0 & 0 & 0 & 0 & 1 & Polymorphism \\
\hline 350 & 1 & 1 & 0 & 0 & 0 & 0 & 0 & 0 & 0 & 0 & Polymorphism \\
\hline 300 & 0 & 1 & 0 & 0 & 0 & 0 & 0 & 0 & 0 & 1 & Polymorphism \\
\hline 200 & 0 & 0 & 1 & 0 & 0 & 0 & 0 & 0 & 0 & 0 & Unique \\
\hline 100 & 0 & 0 & 1 & 0 & 0 & 0 & 0 & 0 & 0 & 0 & Unique \\
\hline
\end{tabular}

RAPD profile scores of ten egusi melon seeds. 1 = KTGO -GMB, 2 = SMATK-KD, 3= GUS-ZAM, 4 = AMIZI-AB, 5 = OFATK-KW, 6 SULTK-NG, 7 = OKIJ-AN, 8= MAD-NG, $9=$ AGWU-EN, and $10=$ MAS-NAS

Table 5 Number of Fragments, Polymorphic Fragments and Percentage Polymorphism revealed by RAPD markers

\begin{tabular}{lcccc} 
Primers & Range of Fragment Sizes in BP & $\begin{array}{c}\text { Total No of } \\
\text { fragment }\end{array}$ & $\begin{array}{c}\text { Polymorphism } \\
\text { Polymorphism }\end{array}$ \\
\hline OPA 13 & $200-1000 \mathrm{bp}$ & 9 & 9 & $100 \%$ \\
OA16 & $800-1000 \mathrm{bp}$ & 2 & 2 & $100 \%$ \\
OA18 & $100-1000 \mathrm{bp}$ & 10 & 10 & $100 \%$ \\
Total & & $\mathbf{2 1}$ & $\mathbf{2 1}$ & $\mathbf{1 0 0 \%}$ \\
\hline
\end{tabular}

Table 6 The Scorable band used for the construction of Dendrogram

\begin{tabular}{|c|c|c|c|c|c|c|c|c|c|c|c|c|c|c|c|c|c|c|c|c|c|}
\hline KTGO-GMB & 0 & 0 & 0 & 1 & 0 & 0 & 1 & 1 & 1 & 0 & 0 & 0 & 0 & 1 & 1 & 1 & 0 & 1 & 0 & 0 & 0 \\
\hline SMATK-KD & 1 & 1 & 1 & 1 & 1 & 1 & 1 & 0 & 0 & 1 & 1 & 0 & 1 & 1 & 0 & 0 & 1 & 1 & 1 & 0 & 0 \\
\hline GUS-ZAM & 0 & 0 & 0 & 0 & 0 & 0 & 1 & 0 & 0 & 0 & 0 & 1 & 0 & 0 & 0 & 0 & 0 & 0 & 0 & 1 & 1 \\
\hline AMIZI-AB & 0 & 0 & 0 & 0 & 0 & 0 & 0 & 0 & 0 & 0 & 0 & 0 & 0 & 0 & 0 & 0 & 0 & 0 & 0 & 0 & 0 \\
\hline OFATK-KW & 0 & 0 & 0 & 0 & 0 & 0 & 0 & 0 & 0 & 0 & 0 & 0 & 0 & 0 & 0 & 0 & 0 & 0 & 0 & 0 & 0 \\
\hline SULTK-NG & 0 & 0 & 0 & 0 & 0 & 0 & 0 & 0 & 0 & 0 & 0 & 1 & 0 & 0 & 1 & 1 & 0 & 0 & 0 & 0 & 0 \\
\hline OKIJ-AN & 0 & 0 & 0 & 0 & 0 & 0 & 0 & 0 & 0 & 0 & 0 & 0 & 0 & 0 & 0 & 0 & 0 & 0 & 0 & 0 & 0 \\
\hline MAD-NG & 0 & 0 & 0 & 0 & 0 & 0 & 0 & 0 & 0 & 0 & 0 & 0 & 0 & 0 & 0 & 1 & 0 & 0 & 0 & 0 & 0 \\
\hline AGWU-EN & 0 & 1 & 0 & 0 & 0 & 0 & 1 & 0 & 0 & 0 & 0 & 0 & 0 & 0 & 0 & 0 & 0 & 0 & 0 & 0 & 0 \\
\hline MAS-NAS & 0 & 0 & 0 & 0 & 0 & 0 & 1 & 0 & 0 & 0 & 0 & 0 & 0 & 0 & 0 & 1 & 1 & 0 & 1 & 0 & 0 \\
\hline
\end{tabular}

The genetic distance (\%) in ten egusi melon accessions based on RAPD pooled over three primers is shown in table 7. Accessions AMIZI-AB, OFATK-KW and OKIJ-AN shows high level of similarity because all the accessions mentioned Dendrogram depicting ten egusi melon seed accessions based on genetic clustered at the same level of coefficient which shows $100 \%$ similarity.

Table 7 Genetic distance (\%) in Ten melon accessions based on RAPD pooled over the 3 primers

\begin{tabular}{|c|c|c|c|c|c|c|c|c|c|}
\hline $\begin{array}{c}\text { KTGO- } \\
\text { GMB }\end{array}$ & SMATK-KD & GUS-ZAM & AMIZI-AB & $\begin{array}{l}\text { OFATK- } \\
\text { KW }\end{array}$ & SULTK-NG & OKIJ-AN & $\begin{array}{l}\text { MAD- } \\
\text { NG } \\
\end{array}$ & $\begin{array}{l}\text { AGWU- } \\
\text { EN }\end{array}$ & $\begin{array}{l}\text { MAS } \\
\text { NAS }\end{array}$ \\
\hline 1.0000000 & & & & & & & & & \\
\hline 0.5238095 & 0.2380952 & 1.0000000 & & & & & & & \\
\hline 0.6190476 & 0.3333333 & 0.8095238 & 1.0000000 & & & & & & \\
\hline 0.6190476 & 0.3333333 & 0.8095238 & 1.0000000 & 1.0000000 & & & & & \\
\hline 0.6666667 & 0.1904762 & 0.7619048 & 0.8571429 & 0.8571429 & 1.0000000 & & & & \\
\hline 0.6190476 & 0.3333333 & 0.8095238 & 1.0000000 & 1.0000000 & 0.8571429 & 1.0000000 & & & \\
\hline 0.6666667 & 0.2857143 & 0.7619048 & 0.9523810 & 0.9523810 & 0.9047619 & 0.9523810 & 1.0000000 & & \\
\hline 0.6190476 & 0.4285714 & 0.8095238 & 0.9047619 & 0.9047619 & 0.7619048 & 0.9047619 & 0.8571429 & 1.0000000 & \\
\hline 0.6190476 & 0.4285714 & 0.7142857 & 0.8095238 & 0.8095238 & 0.7619048 & 0.8095238 & 0.8571429 & 0.8095238 & 1.0000000 \\
\hline
\end{tabular}




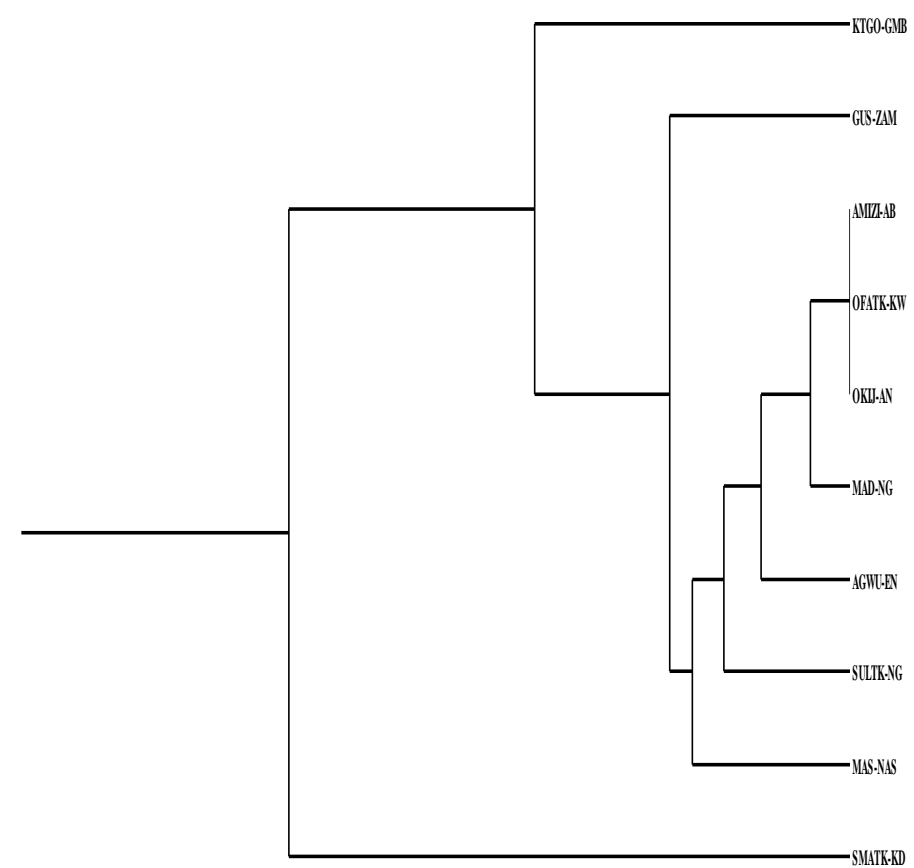

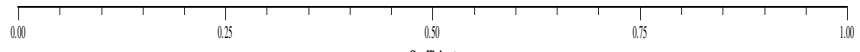

Figure 8 Dendograms depicting Ten egusi Melon seeds accessions based on their genetic characteristics.

\section{DISCUSSION}

This study was conducted to determine ten Egusi melon seed accessions morphology including mean seed weight, percentage seed fat and protein content as well as its genetic relatedness and variation. Observed among the accessions studied were the Range of seed sizes and their colors. The morphological features of the seeds revealed they range in size from medium to large brown or golden yellow seeds with thin or thick edge which supports the studies by Mohr $\underline{\mathbf{( 1 9 8 6 )}}$ that seeds of melon crops, ranged in size from very small seed size to large seed sizes.

The mean percentage protein content ranged from 13.90-14.00 and 23.36-23.63\% with KTGO-GMB (23.5) having the highest value, which was significantly different $(\mathrm{p}<0.05)$ from other samples. The results obtained for these egusi melon seeds does not agree with the findings of Ndukauba et al., (2015) and Fakou et al., (2004) who revealed a range of $28.62-30.67 \%$ in twenty eight melon seeds and a range of $24.3-41.6 \%$ for protein content in five melon seeds respectively. The values obtained from this study were closer to the values $(23.7$ $30.68 \%)$ and (25.05-25.82) reported by Olaofe $\boldsymbol{e t}$ al., (1994) and Onyemize $\boldsymbol{e}$ al., (2017) respectively for melon seeds. KTGO-GMB and OKIJA-AB could be used to supplement food products because of their excellent protein content

Egusi seed accessions SMATK-KD (43.90) and MAD-NG (43.69) had the highest percentage mean fat value with a range of 43.84-43.95 and 43.66-43.72 respectively while KTGO-GMB (20.07) had the least value with a range of 20.05-20.09, which was significantly different $(\mathrm{p}<0.05)$ from the other accessions. This result agrees with that of Abiodun and Adeleke, (2010) that fat content of four species of four melon seeds ranged from $40.26-45.21 \%$. It also agrees with the findings of Ndukauba et al (2015), for 28 melon seeds accessions. These results were also closer to the values $(48.89-49.96)$ reported by Onyemize et al.,(2017) for fat content in two varieties of egusi melon All the samples except KTGO-GMB have high fat contents, this classifies Egusi melon seeds accessions as excellent sources of dietary oil (Abiodun and Adeleke, 2010).

The results obtained for seed weight revealed that AGU-ENU (12.90) and KTGO-GMB (12.45) has the highest mean weight obtained for 100 seeds with a range of 12.40-13.40 and 12.10-12.80, which were significantly different ( $\mathrm{p}<$ 0.05 ) from other accessions. Other results obtained for seed weight revealed that OKIJA-AN (10.8) and MAS-NAS (10.90) has the least mean weight obtained for 100 seeds with a range of $10.2-11.40$ and $10.10-11.70$, which were significantly different $(\mathrm{p}<0.05)$ from other accessions. These results agree with the findings of Ndukauba et al., (2015), which revealed a range 8.23-13.03 for 28 melon seed genotypes. These results were also closer to the values (14.27-15.58) obtained by Idehen, (2017) for mean weight of 100 melon seeds.

RAPD analysis was done individually with 3 random decamer primers (OPA 13; OPA 16 and OPA 18) according to the method of Williams et al., (1993).
The RAPD profiles of ten accessions of egusi melon were separately compared to find out the differences among them by the occurrence of polymorphic bands The percentage polymorphism was calculated using $\mathrm{Nei}$.and $\mathrm{Li}$ formula (Ne and $\mathbf{L i},(\mathbf{1 9 7 9}) .21$ scorable bands were produced in ten accessions with 3 primers. The number of bands produced per primer varied from two for OPA 13 nine for OPA 16 and ten for OPA-18. The average number of bands per primer was 7 out of 21 and 10 were polymorphic $(47.62 \%)$. The average number of polymorphic bands was 7 per primer only. These findings concurs with that of Mihalte et al., (2011) that RAPD fragments vary with primers as well as species All the identifiable RAPD bands for the three primers were polymorphic. The primers OPA-13, OPA-16 and OPA-18 produced 100 per cent polymorphism. This result is close to the findings of Idehen et al (2007) that 50 accessions of egusi Melon show $93.60 \%$ polymorphism. The results of dendrogram obtained from the pooled data revealed high level of dissimilarity or diversity of $67.5 \%$ among the accessions of the melon. The results agree with the findings of Jacob et al., (2016) that 5 melon seeds obtained (51\%) variation and that these variations were attributed to variation within individuals. The dendrogram constructed for pooled data show two major clusters, the KTGO-GMB and SMATK-KD. The accession KTGO-GMB was found in another cluster distinctly separated from other accessions. Within the sub-clustered GUS-ZAM accession revealed some level of dissimilarity when compared with other accessions such as AMIZI-AB, OFATK-KW, OKIJ-AN,, MAD-NG, AGWU-EN, SULTK-NG and MAS-NAS. However it was interesting to observe that within this subcluster, AMIZI-AB, OFATK-KW and OKIJ-AN shows high level of similarity because all the accessions mentioned clustered at the same level of coefficient which shows $100 \%$ similarity. The rest of the accessions were found in another sub-cluster showing low level of dissimilarity among each other.

The amount of genetic diversity observed in molecular studies depends on the number and the types of primers used and amount of diversity among the accessions used in the investigation (Mliki et al., 2001)

The genetic diversity observed in this study could be attributed to either the divergent lines examined or the wide geographical spread of the melon accesssions. Furthermore, the selected primers were able to recognize the genetic differences among accessions.

\section{CONCLUSION}

It is known that egusi melon is an excellent source of important nutrients such as fat and protein. From the results, SMATK-KD, MAD-NG, and AGU-ENU are excellent sources of fat while KTGO-GMB and OKIJA-NG are excellent sources of protein. These egusi melon seeds are valuable dietary supplements especially for people in the rural areas where there are lack of adequate access to dairy foods and meats.

RAPD markers are suitable in assessing genetic diversity and can aid the identification of desirable qualities for the introduction of new genes into breeding materials. This study serves as a basis to encourage further characterization of Egusi melon seed accessions.

Acknowledgement: I wish to sincerely thank the Laboratory Staff of the Department of Biological Sciences Nigeria Defence Academy for their support while carrying out this research work

\section{REFERENCES}

Abiodun O.A and Adeleke R.O, (2010). Comparative Studies on Nutritional Composition of Four Melon Seeds Varieties. Pakistan Journal of Nutrition, 9: 905-908. http//doi:10.3923/pjn.2010.905.908.

Abrefa, D. J. (2003). In: Tropical Crops, agricultural science and resource management in the tropics and subtropics Field and vegetable crops PTS 130 Wintersemester Bonn. Germany pp.5-8.

Achu, M. B., Fokou, E., Techigang, C., Fotso, M. and Techonanguep, F. M. (2005). Nutritive value of some cuansitacea ion seed from different regions in Cameroon. Afr.I.Biotech, 4:1329 - 1334 http//doi.org/10.5897/AJB2005.000$\underline{3263}$

Adewusi, H., Ladipo, D.O., Sarumi, M.B., Adebisi, A.A and Vodonhe, R. (2000). Egusi production, utilization and diversity in Nigeria.Complled by Akoroda, M.O. In: Agronomy in Nigeria, Dept. of Agronomy, University of Ibadan, Ibadan, Nigeria. pp 67-75

Adeyemo, M.O, and Ojo, A.A. (1991).Genetic variability and associations of some agronomic traits and seed yield in Sesame (Sesamum indicum L.). Nigeria J. Genet. VIII: $39-44$.

Akpambang, V. O. E., Amoo, I. A. and Izuagie, A. A. (2008). Cooperative compositional analysis on two varieties of melon (Colocynthis citrllus and Cucumeropsis edulis) and a variety of almond (Prunus amydalus).Research Journal of Agriculture and Biological Science 4(6): 639 - 642.

Anuebunwa, F.O. (2000). A Bio - economic on - farm evaluation of the use of sweet potato for complementary weed control in a yam/ maize/egusi/cassava inter crop in pigeonpea hedgerous in the rainforest belt of Nigeria. Biological $\begin{array}{lll}\text { Agriculture } & \text { Horticulture 18:95 }\end{array}$ http//doi.org/10.1080/01448765.2000.9754872 
Ayodele, O. J. and Salami, A. E. (2006). Population requirements of egusi melon (Citrullus lanatus) In a humid environment. Proceedings of $23^{\text {rd }}$ Annual Conference. pp. $286-291$.

Development, Security and Cooperation (DSC) (2006). Lost crops of Africa. Vol II: Vegetables. 500 Fifth St. N. W. Washington D. C. 2001, pp $154-171$ http//doi.org/10.17226/2305

Doyle, J. J. Doyle, J. L. (1987). A rapid DNA Isolation procedure of Small quatities of fresh leaf tissue. Phytochem Bull; 19, 11-15.

Erdine A., (2015) Morphological and Molecular Chararterization of Turkish landraces of cucumis melo L J. Amer. Soc. mol Sci. 111: 335 - 380.

Ezeike, G.O.I and Otten, I. (1989).Two-Compartment model for drying unshelled egusi (melon) seeds. Am. Soc. Agric. Eng. 89:1 - 20.

Fakou, E., Achu, M. B. and Techonarguep, M. F. (2004). Preliminary nutritional evaluation of five species of egusi seeds in Cameroon. Afr. J. Food Agric. 4 (1) 1-3 http//doi.org/10.43/ajfand.v4i1.19151

Fayemi, P. O. (1999). Nigerian vegetables. 1. Heinemann Educational Books. Nigeria. 237

Garcia, E., M. Jamilena, J.I. Alvarez, T. Arnedo, J.L. Oliver and R. Lozano, (1998). Genetic relationships among melon breeding lines revealed by RAPD markers and agronomic traits. Theor. Applied Genet. 96: 878885.http/doi.org/10.1007/s001220050815

Garco-Rodrigez, E., I. Alvarez and R. Lozano, (1996). Random Amplified Polymorphic DNAs (RAPDs) as markers to determining genetic relationships among Cucumis melo L. genotypes. Proceedings of the 6th Eucarpia Meeting on Cucurbit Genetics and Breeding, May 28-30, 1996, Malaga, Spain, pp: 187-193.

Idahosa, D. O., Alika, J. E. and Omgregre, A. U. (2010). Genetic variability, heritability and expressed genetic advance as indices for yield and yield components selection in cowpea (Vigna unguiculata (L) walp. Academia Arena 2 (5): $22-26$.

Idehen E.O. (2017) Evaluation of agronomic characters of Egusi Melon genotypes from various agro ecological zones Of Nigeria, Pragon Czech republic journal of biotechnology 17-19

Idehen, E. O., Kehinde, O.B. and Adegbite, A.E. (2008). Somatic chromosome counts and yield performance of some accessions of 'egusi' melon (Citrullus lanatus) African Journal of Biotechnolgy 5 (22): 2049 - 2052 http//doi:10.4314/njg.v2oi1.42253

Idehen, E.O., Kehinde, O.B. and Ariyo, O. J. (2007). Numerical analysis of variation among Nigerian accessions of 'egusi' melon (Citrullus lanatus (Thumb.) Matsum and Nakai. Journal of American Science 3 (2): 1 - 6.

Jacob M., Hussein L., Alfred O. (2016) Simple sequence repeat markers revea diversity within and among landrace collections of citron and used water melon from South Africa African Journal of Agricultural Research 2 (8): 114 13.http//doi:10.21273/jashs03870-16

Jolaoso, M.A., Ojeifo, I.M. and Aiyelaagbe, I.O.O. (1996).Productivity of plantain (Musa AAB) melon mixtures in Southeastern Nigeria. .Biol. Agric Hort 13: 335 - 340.http//doi:10.1080/01448765.1996.9754791

Makinde E. A., O.T.Ayuola, O. T. and Akande, M. U. (2014) Effects of Organo mineral Fertilizer Application on the Growth and Yield of 'Egusi' melon. Australian Journal of Basic and Applied Science 1(1):15 - 19

Mihalte, L. Sestras, R. Feszt., Sestraz, A. F. (2011) Variability of seed traits in interspecific and inter-generic combination between different genotypes N. Bot Horti Agrobo (38(3): 246-252.

Mliki, A., J.E. Staub, S. Zhangyong and A. Ghorbel, (2001). Genetic diversity in melon Cucumis melo L. an evaluation of African germplasm. Genet. Res. Crop. Evol. 48: 587-597

Mohr, H.C. (1986).Watermelon breeding.In Basset M. J. Breeding Vegetable crops.Westport, C.T. AVI Publ. pg 37 - 66.

Ndukauba J., G. E. Nwofia , P. I. Okocha, E. E. Ene-Obong (2015) Variability in Egusi-Melon Genotypes (Citrullus lanatus (Thumb) Matsum and Nakai) in Derived Savannah Environment in South-Eastern Nigeria. International Journal of Plant Research 2015, 5(1): 19-26. http//doi:10.5923/j.plant20150501.04

Nei M., Li W.H (1979) Mathematical model of studying genetic variation in terms of restriction endonucleses Pro Natl Acad Sci. USA 10:5269.

Ogbonna, P.E. and Obi, I. U. (2007). Effects of time of planting and poultry manure application on growth and yield of egusi melon (Colocynthis citrullus L.) In a Derived Savannah Agro - Ecology. Agro - Science 6(2):33 - 38 http/doi.org/10.4314/as.v6i2.1568

Ojeifo, I.M., and F.N. Emuh (2009). Effect of fruit size, injury Infection Techniques and Post Injury handling on Rolting of Citrullus lanatus(Egusi melon). Fruit for seed extraction. Agricultura Tropica et subtropica 42(4): 187 189

Ojieh G, oluba O, Ogunlowo K (2008) Compositional stdies of Citrullus lanatus (Egusi Melon) seed. Journal of nutrition and wellness volume 6, number 1. http//doi.org/10.5580/e6fs

Olaefa, O., Adeyemi, F. O. and Adeniran, G.O. (1994). Amino acid and mineral composition and functional properties of some oil seeds. J. Agri. Food Chem., 42:878 - 884. http//doi.org/10.1021/jf00040a007
Onyemize U.C, Ozumba I, Chukwu C (2017) comparative evaluation of manually and mechanically shelled Egusi Melon. American journal of food sciences and nutrition research vol 4, no 2 .

Pearson, D. (1976). Chemical analysis of foods, $7^{\text {th }}$ edition, Churchil Hill Living Stone London.

Podani, J. E. (2016) Extending Gower's general coefficient of similarity to ordinal characters and Taxon. Longmans, Green and Co. ltd. 227 pages

Rehm, S., Espig, G. (1991). The cultivated plant of the tropics and subtropics: Cultivation, economic values and utilization. Institute of Agronomy in the tropics, University of Gottingen. 321pages http//doi.org/10.1017/s026646740000612X

Schippers, R. R. (2000). African Indigenous vegetables. An Overview of the cultivated species. Chattam, Uk: Natural Resources Institute/ACP - EU Technical Centre for Agricultural and Rural Cooperation, 224pages

Silberstain A., and Wagar A., (1999) DNA finger printing of essential commercialized medicinal plants from Pakistan, School of Biological Sciences University of the Punjas Lahore Pakistan

Staub, J.E., Y. Danin-Poleg, G. Fazio, T. Horejsi, N. Reis and N. Katzir (2000). Comparative analysis of cultivated melon groups Cucumis meloL. using random amplified polymorphic DNA and simple sequence repeat markers. Euphytica, 115: 225-241. http//doi.org/10.21273.hortsci.35.3.397b

Williams, J.T. and Isaq, N. (2002).Global research on underutilized crops.An assessment of current activities and proposal for enhancement cooperation. Southanption, Uk: ICUC. pp 49-6

William, R. L. and Pollack, E. (1993).Theory of heterosis. .Journal of Diary Increase 68: 2411-2417

http//doi.org/10.3168/jds.s0022-0302(85)81117-6

Zhang, Z., Zhongfu, N., Yingyin, Y. and Qixin, S. (2012). Gibbererellins and heterosis of plant height in wheat (Triticum aestivum L.) BMC. Genet. 8 (40): 1471-2156. http//doi.org/10.1186/1471-1256-8-40 